\title{
DNA CONTENT AND MORPHOLOGICAL PROPERTIES OF PRESUMABLY ANEUPLOID SPERMATOZOA OF TOBACCO MOUSE HYBRIDS
}

\author{
L. DÖRING, A. GROPP* AND U. TETTENBORN \\ Abteilung für Kinderpathologie am Pathologischen Institut der Universität Bonn/Rh., \\ Fed. Rep. Germany
}

(Received 12th Fuly 1971, accepted 27th September 1971)

\begin{abstract}
Summary. A sharp reduction in fertility of the $F_{1}$ hybrids between the tobacco mouse ( $M$. poschiavinus) and the laboratory mouse can be attributed to irregular segregation of trivalents in meiotic anaphase I. In male meiosis, more than $50 \%$ of aneuploid secondary spermatocytes are produced. The cytophotometric measurements of the relative FeulgenDNA content of cytologically mature, morphologically normal spermatozoa revealed a significantly greater variation in $F_{1}$ males as compared to $M$. poschiavinus and the laboratory mouse. This difference is regarded as being due to the presence of a considerable fraction of aneuploid spermatozoa. Obviously, they are derived from the aneuploid precursor cells and have developed normally in spite of their abnormal number of chromosomes. However, the frequency of malformed spermatozoa was also higher in $F_{1}$ males than in the parental strains. The additional analysis of the number of spermatozoa, their motility and the respective proportions of living or dead spermatozoa and of spermatozoa with normal or abnormal acrosomal caps did not show differences between $F_{1}$ males and the parental strains. The head area of $F_{1}$ spermatozoa was markedly reduced.
\end{abstract}

\section{INTRODUCTION}

It has been established that reproductive failure due to fetal aneuploidy resulting from irregular meiotic segregation in gametogenesis is an important feature in man (Carr, 1970) as well as in other mammalian species (Ford, 1970). Qualitative and quantitative analyses of this phenomenon were provided by an investigation of the factors responsible for the sharp reduction of fertility in $\mathrm{F}_{1}$ hybrids of the tobacco mouse, $M$. poschiavinus, and the laboratory mouse (Gropp, Tettenborn \& von Lehmann, 1970). The $F_{1}$ hybrids are heterozygous for seven Robertsonian fusion metacentrics, and, therefore, they display seven trivalents in meiosis I. These peculiar cytological conditions enhance irregular segregation in meiotic anaphase I, thereby producing considerable gametic aneuploidy (Tettenborn \& Gropp, 1970) and, consequently, a great proportion

\footnotetext{
* Reprint requests to: Dr A. Gropp, Pathologisches Institut d. Universität, D-53 Bonn, Fed. Rep. Germany.
} 
of chromosomally unbalanced, mostly lethal zygotes (Gropp, Giers, Ford, Clegg \& Evans, in preparation). There is, therefore, evidence that aneuploid spermatogenic or oogenic precursor cells develop to mature gametes which are, at least in part, capable of fertilization.

The observations presented in this report extend and supplement earlier studies on regular versus irregular meiotic segregation in $\mathbf{F}_{1}$ hybrid males as compared to the tobacco and laboratory mouse (Tettenborn \& Gropp, 1970). The main objective of this study, however, was to measure the DNA content in cytologically mature epididymal spermatozoa. In addition, the morphology and motility of the spermatozoa were investigated.

The results of these studies and their comparative analysis should answer the question of whether or not the majority of aneuploid secondary spermatocytes, as revealed by abnormal metaphase II counts, develop to functioning epididymal spermatozoa.

Animals

\section{MATERIALS AND METHODS}

For the morphological and functional analyses and for DNA measurements of epididymal spermatozoa, twelve male tobacco mice ( $M$. poschiavinus) from our laboratory stock, twenty-seven males of a laboratory mouse strain ('NMRI' Hannover) and thirty-two male $\left(M\right.$. poschiavinus ${ }^{\lambda} \times \mathrm{NMRI}$ ( ) $\mathrm{F}_{1}$ hybrids were used. Meiotic preparations of three additional tobacco mouse males, four NMRI males and three $F_{1}$ males were made to supplement the meiotic metaphase II data presented by Tettenborn \& Gropp (1970). All animals were between 10 and 16 weeks old.

The tobacco mouse has a diploid chromosomal set of 26 (Pl. 1, Fig. 1) with 7 pairs of fusion metacentrics (Nombre fondamental (N.F.) $=40$ ). In $F_{1}$ hybrids, the somatic cells invariably show 33 chromosomes (PI. 1, Fig. 1) including 7 heterozygous metacentrics (N.F. $=40$ ).

\section{Meiotic preparations}

The occurrence of abnormal chromosomal segregation in meiotic anaphase I can be detected by the numerical evaluation of metaphase II figures. A $0 \cdot 3-\mathrm{ml}$ vol. of colchicine $(0.5 \%)$ was injected intraperitoneally $3 \mathrm{hr}$ before the animals were killed. Air-dried preparations (Evans, Breckon \& Ford, 1964) were stained with acetic orcein. They yielded sufficient numbers of M II figures for the score of 100 plates per animal. The total number of chromosome arms (N.F./2) as well as the number of chromosomes (n) and metacentrics were recorded for each metaphase II plate. However, according to the procedure applied in a previous study (Tettenborn \& Gropp, 1970), only the number of chromosome arms was used for determining metaphase II euploidy (N.F./2 $=20$ ) or aneuploidy (N.F./2 $>$ or $<20$ ).

\section{Assays for DNA content of spermatozoa}

Spermatozoa were obtained from the vas deferens immediately after killing the animals. Smear preparations of spermatozoa from individual $F_{1}$ males were made simultaneously on separate areas of the same slide together with smears of 


\section{PLATE 1}

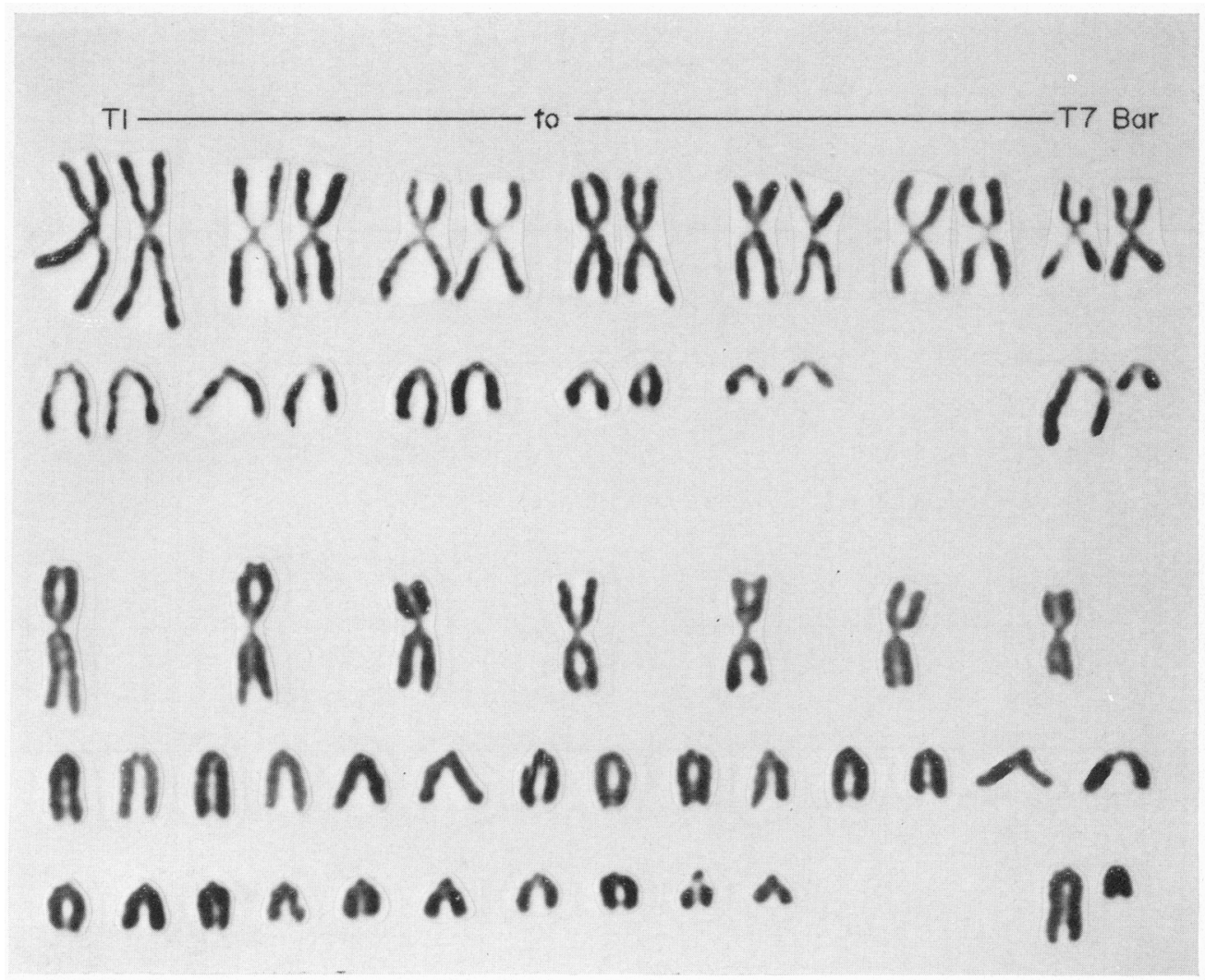

Fig. 1. Somatic karyotype of a male tobacco mouse (top), M. poschiavinus, and of a male $\mathrm{F}_{1}$ hybrid (bottom). The metacentric chromosomes are designated by the symbols T1 to 7 Bnr as proposed by Gropp, Tettenborn \& Léonard (1970). 

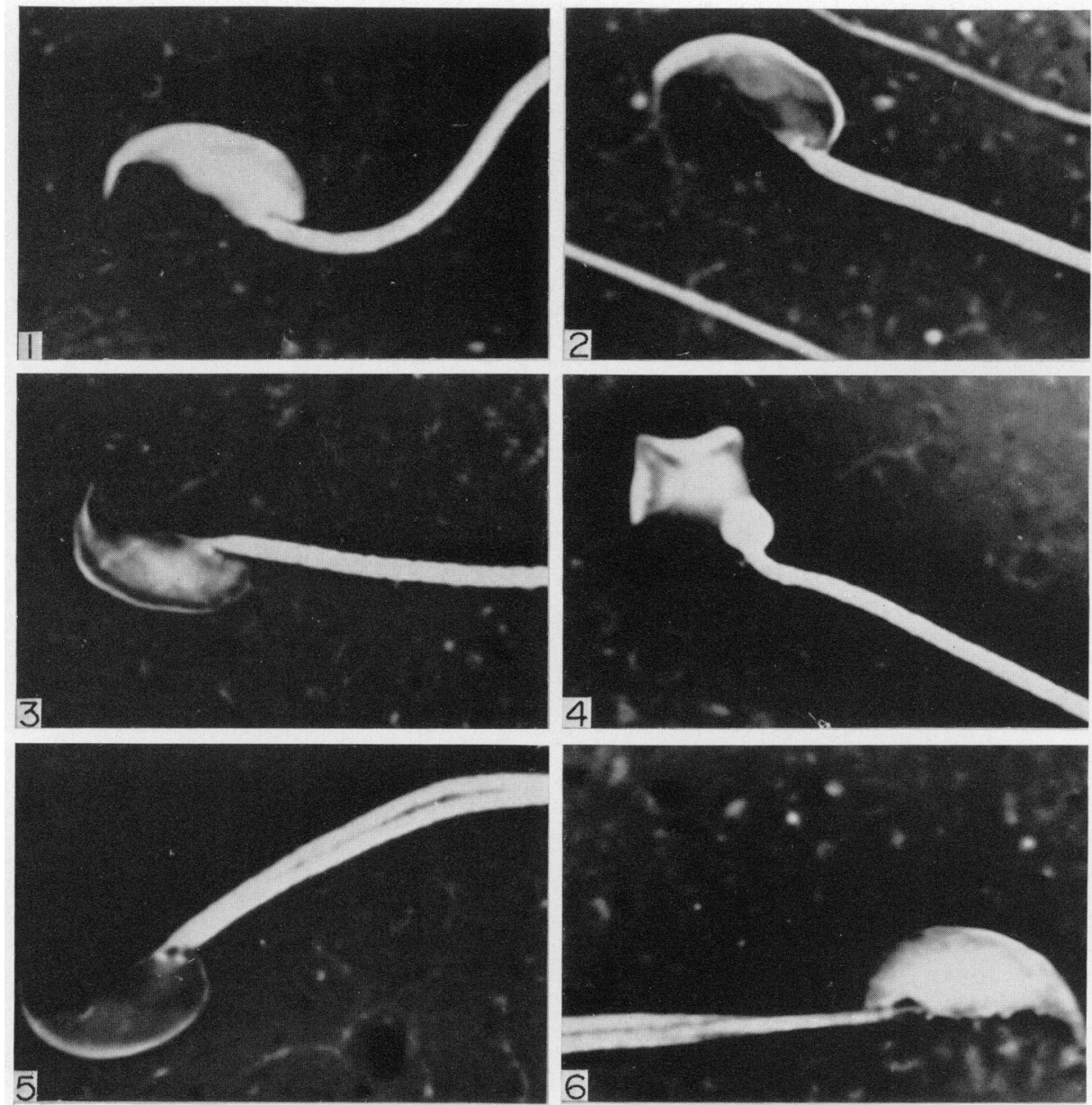

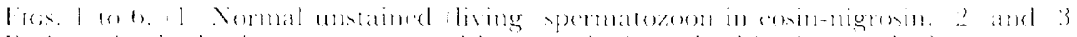

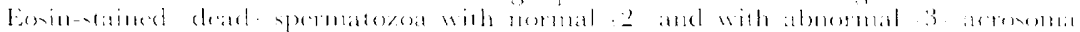

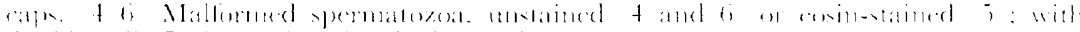

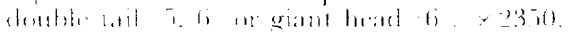


either tobacco or (NMRI) laboratory mouse spermatozoa. In this manner, a series of smears (Series I; Table 2) of spermatozoa from each of nine $F_{1}$ hybrids were arranged on the same slide with a smear from one of nine NMRI males. Similarly, in another series (Series II; see Table 2), corresponding smears of five $F_{1}$ and five tobacco mouse males were made. The fresh, wet smears were fixed (1 hr) in ethanol:formalin, 9:1, and then kept until hydrolysis (the same or the following day) in $96 \%$ ethanol. Immediately before hydrolysis $(11 \mathrm{~min}$ in $\mathrm{N}-\mathrm{HCl}$ at $60 \pm 1^{\circ} \mathrm{C}$ ), the smears were rinsed in water for $20 \mathrm{~min}$. Feulgen staining (Schiff solution, $1 \mathrm{hr}$ ) was carried out simultaneously and in one working procedure for all the slides of each series. As a control procedure, hydrolysis was omitted in one slide of each series. These slides were negative.

Feulgen-DNA measurements. Using a Barr \& Stroud Integrating Microdensitometer, Type G.N., for cytophotometric measurements, at least fifty or more morphologically normal spermatozoa per mouse were selected. The conditions under which the measurements were carried out were: lamp $9 \mathrm{~V}$; filter $550 \mathrm{~nm}$; objective $\times 100$; aperture 1.30 ; ocular size $\times 10$; extinction level 0.75 ; absorption range 5 .

\section{Sperm counts}

The number and density of the spermatozoa obtained from the vas deferens of nine NMRI and $F_{1}$ males were determined in two counts for each mouse in a Fuchs-Rosenthal chamber.

\section{Morphological criteria of spermatozoa and assays for viability and motility}

Fresh smears of spermatozoa were treated with eosin-nigrosin stain (Hancock, 1951 ; Beatty \& Sharma, 1960) for the differentiation of viable (unstained) and dead (eosin-stained) spermatozoa. The observations of this staining method and some additional criteria were recorded for evaluation of:

(a) proportion of living (unstained) spermatozoa (PI. 2, Fig. 1); 2);

(b) proportion of spermatozoa with a 'normal' acrosomal cap (Pl. 2, Fig.

(c) proportion of malformed spermatozoa: slight or heavy (Pl. 2, Figs. 3 and 4) malformations of the sperm head, giant heads (P1. 2, Fig. 6) duplication of the tail (Pl. 2, Figs. 5 and 6);

(d) size of living 'normal' spermatozoa as measured by the area occupied by the head. Planimetric measurements were taken from photographs (negatives) projected on a screen.

Nine NMRI, seven tobacco mouse and nine $F_{1}$ males were used for these studies, with the exception of the estimation of living spermatozoa for which only six $F_{1}$ males were available. The respective counts refer to 200 spermatozoa per animal for the number of living spermatozoa and of spermatozoa with a normal acrosomal cap, and to 300 cells for the estimation of malformed spermatozoa. For the planimetric measurements of the head area, ten spermatozoa were randomly selected from each of the same animals.

The motility of the spermatozoa was determined according to the criteria established by Emmens (1947). The following two suspension media were 


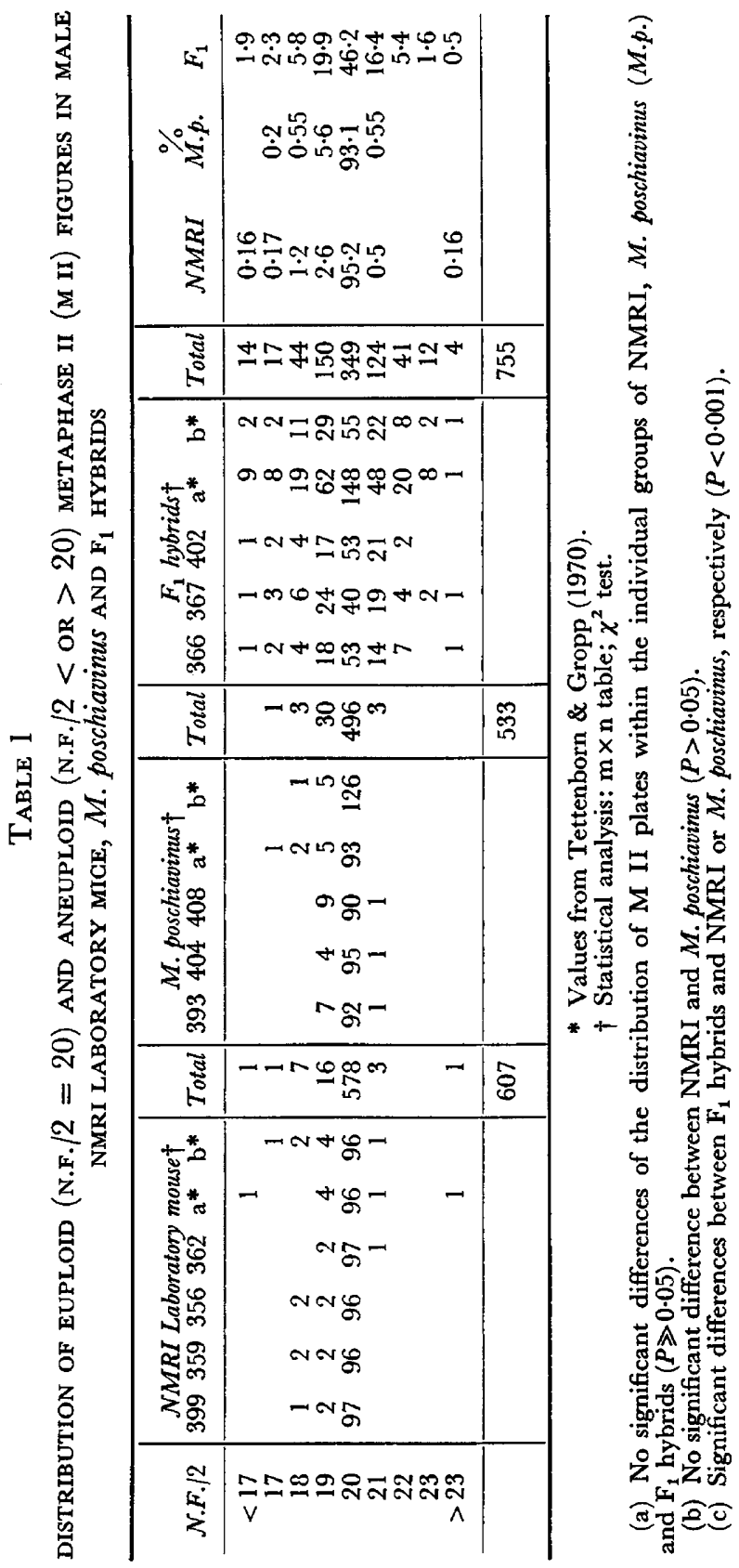


used: (a) $3 \%$ glucose, $0.4 \% \mathrm{NaCl}$, (b) Ringer solution $(0.9 \% \mathrm{NaCl} ; 0.042 \%$ $\mathrm{KCl})$.

\section{RESULTS}

Segregation of chromosomes in first meiotic anaphase (euploidy/aneuploidy of spermatocytes II)

In addition to the end-to-end associated $\mathrm{XY}$ bivalents, diakinesis figures of meiosis I invariably showed 19 and 12 autosomal bivalents in NMRI and $M$. poschiavinus respectively, and 7 chain trivalents together with 5 bivalents in the $F_{1}$ hybrids (Gropp, Tettenborn \& von Lehmann, 1970).
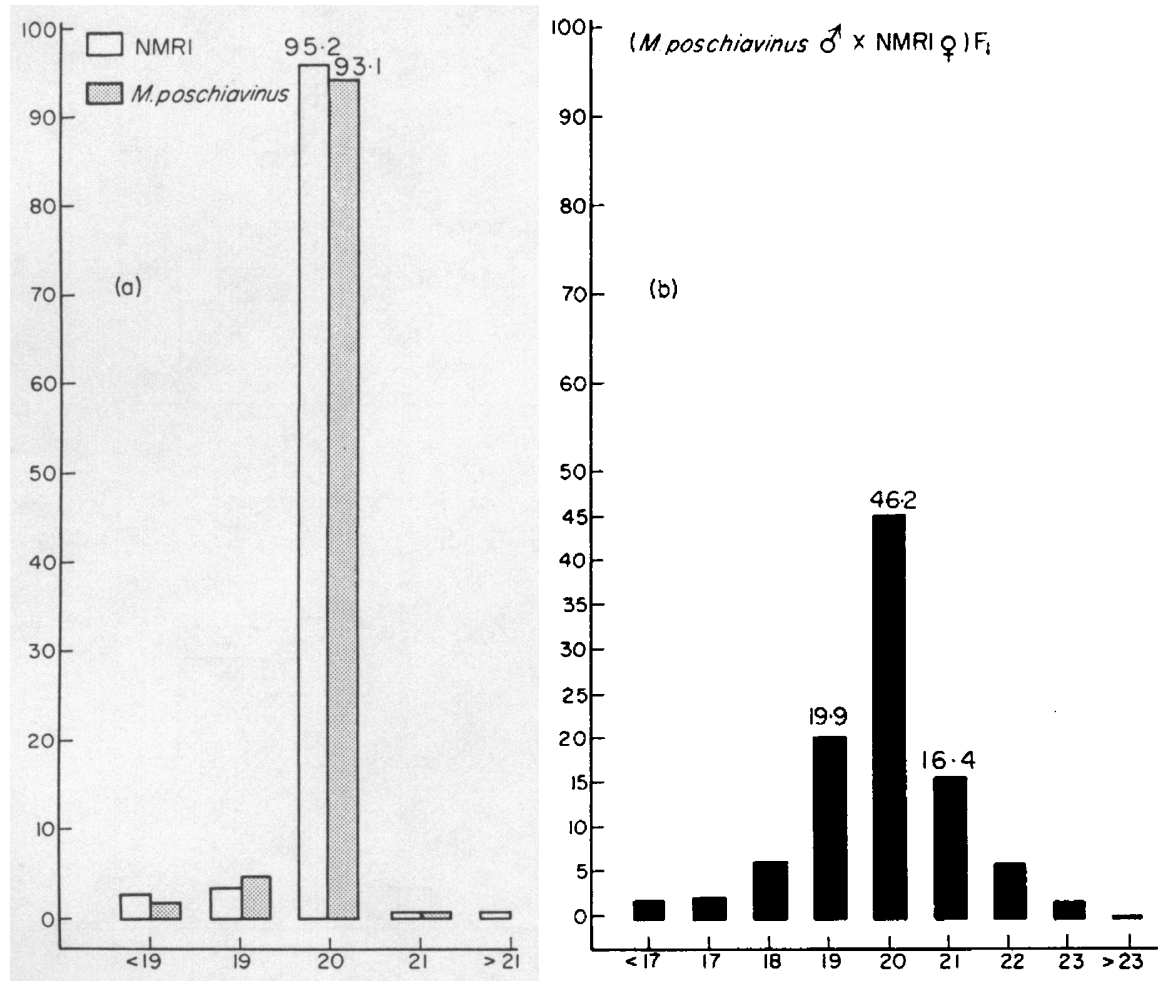

Text-Fig. 1. Frequency diagram showing the distribution of euploid (N.F./2=20) and aneuploid metaphase II counts in spermatocytes of NMRI and $M$. poschiavinus (a) and $F_{1}$ hybrids (b).

Counts of chromosome arms (N.F./2) were made in a total of $607 \mathrm{M}$ II plates of six NMRI males, in 533 plates of five tobacco mouse males and in 755 plates of five $F_{1}$ hybrid males. Data from a former investigation (Tettenborn \& Gropp, 1970; see Table 1) are included in these numbers, which are a composite of additional data collected by a study of more animals. Table 1 shows the distribution of the counts of the euploid (N.F./2 = 20) and the hypo- or hypermodal (N.F. $2<$ and $>20)$ M II plates. Their relative percentile proportions are further represented in Text-fig. 1a and b. In the parental strains, NMRI and $M$. poschiavinus, the frequency of the euploid M II plates considerably exceeded 
$90 \%(95 \cdot 2$ and $93 \cdot 1 \%$, respectively). There was a low peak of only $46 \cdot 2 \%$ euploid $\mathrm{M}$ II plates in the $\mathrm{F}_{1}$ males and the presence of a considerably broader dispersion of values. In all three groups, the variation from the euploid value (N.F./2 $=20$ ) was not completely symmetrical. There was an excess of hypomodal counts which may have resulted from artificial losses of chromosomes due to the spreading procedure.

The mathematical analysis of the distribution of M II counts did not reveal statistically significant differences of the individual specimens within each of the three groups (NMRI, $M$. poschiavinus and $\mathrm{F}_{1}$ ). There was also no significant

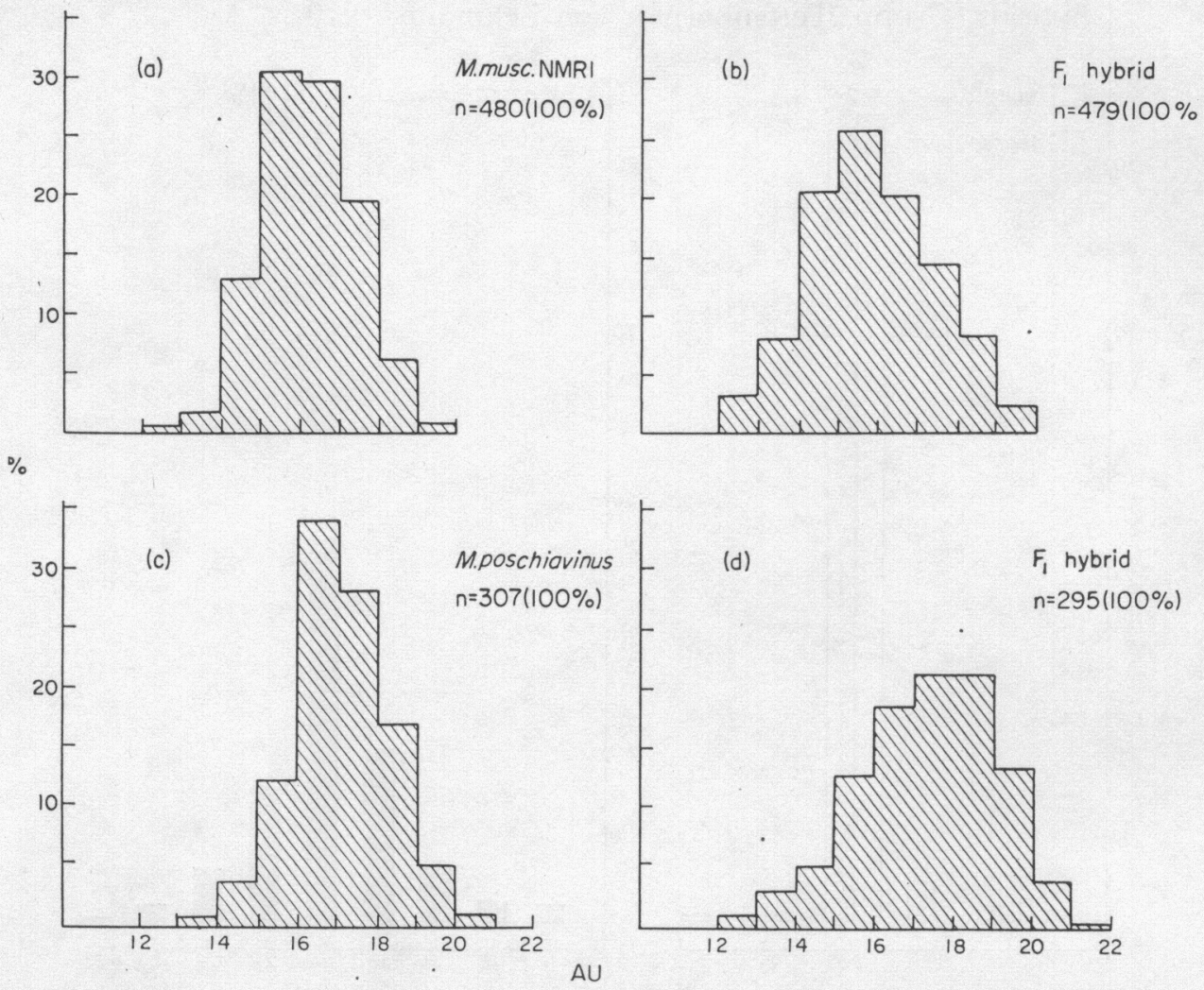

Text-Fig. 2. Histograms representing the statistical variation of the Feulgen-DNA content as revealed by two comparative measurements of spermatozoa from NMRI compared to $F_{1}$ ( $a$ and $b$; see Table 2, Series $I$ ) and from $M$. poschiavinus compared to $F_{1}$ (c and d; see Table 2, Series II).

difference between the NMRI- and $M$. poschiavinus-males $(P>0.05)$. However, the differences of the distribution of the $M$ II counts in $F_{1}$ males were statistically significant in comparison to NMRI and $M$. poschiavinus $(P<0.001)$ (see Table 1).

\section{Feulgen-DNA measurements of spermatozoa}

The histograms of Text-fig. 2a to d show the distribution of the Feulgen-DNA values of the spermatozoa of $F_{1}$ hybrids as compared to spermatozoa of the 
parental NMRI laboratory mouse strain and $M$. poschiavinus. Lower peaks and a definitely broader variation of the Feulgen-DNA values characterize $\mathbf{F}_{1}$ males. This is documented by the comparative measurements of $F_{1}$ and NMRI (Table 2, Series I; Text-fig. 2a and b) and of $F_{1}$ and $M$. poschiavinus as well (Table 2, Series II; Text-fig. $2 \mathrm{c}$ and d).

Detailed data of the absorption values as measured in the individual animals are represented in Table 2 (Series $\mathbf{I}$ of comparative measurements of nine $\mathbf{F}_{1}$ and nine NMRI; Series II comprising five $F_{1}$ and five $M$. poschiavinus). Since the absorption measurements of $\mathrm{F}_{1}$ versus NMRI or $M$. poschiavinus were carried out on spermatozoa fixed, hydrolysed and stained on the same slide,

TABLE 2

FEULGEN-DNA ABSORPTION VALUES OF MOUSE SPERMATOZOA: SERIES I, COMPARATIVE MEASUREMENTS OF $F_{1}$ AND NMRI; SERIES II, COMPARATIVE MEASUREMENTS OF $F_{1}$ AND $M$. poschiavinus

\begin{tabular}{|c|c|c|c|c|c|}
\hline $\begin{array}{c}\text { Preparation } \\
\text { no. }\end{array}$ & $\begin{array}{c}\text { Spermatozoa } \\
n\end{array}$ & $A U \pm S . D$ & $\begin{array}{c}\text { Spermatozoa } \\
n\end{array}$ & $A U \pm S . D$ & $P_{F}$ \\
\hline Series I & \multicolumn{2}{|l|}{$F_{1}$ hybrids } & \multicolumn{2}{|c|}{ NMRI laboratory mouse } & \multirow{3}{*}{$\begin{array}{l}1.24 P>0.10 \\
2.59 P<0.005 \\
1.69 P<0.05 \\
1.32 P>0.10 \\
1.68 P<0.05 \\
2.67 P<0.005 \\
1.76 P<0.05 \\
1.58 P<0.05 \\
2.47 P<0.005\end{array}$} \\
\hline $\begin{array}{l}1 \\
2 \\
3 \\
4 \\
5 \\
6 \\
7 \\
8 \\
9\end{array}$ & $\begin{array}{l}51 \\
62 \\
54 \\
52 \\
51 \\
50 \\
50 \\
55 \\
54\end{array}$ & $\begin{array}{ll}15 \cdot 20 & 1.37 \\
16.63 & 1.60 \\
16 \cdot 11 & 1.55 \\
15 \cdot 18 & 1.41 \\
16.21 & 1.38 \\
15 \cdot 12 & 1.68 \\
16.37 & 1.40 \\
14.63 & 1.33 \\
15.94 & 1.54\end{array}$ & $\begin{array}{l}50 \\
60 \\
51 \\
55 \\
50 \\
50 \\
50 \\
54 \\
60\end{array}$ & $\begin{array}{ll}15.68 & 1.23 \\
15.77 & 0.99 \\
16.40 & 1.19 \\
16.02 & 1.23 \\
15.59 & 1.07 \\
16.69 & 1.03 \\
15.35 & 1.06 \\
16.72 & 1.06 \\
16.44 & 0.98\end{array}$ & \\
\hline Total & 479 & 15.711 .47 & 480 & $16.07 \quad 1.09$ & \\
\hline SERIES II & \multicolumn{2}{|l|}{$F_{1}$ hybrids } & \multicolumn{2}{|c|}{ M. poschiavinus } & \multirow{3}{*}{$\begin{array}{l}1.92 P<0.01 \\
2.07 P<0.01 \\
1.85 P<0.01 \\
1.63 P<0.05 \\
2.09 P<0.005\end{array}$} \\
\hline $\begin{array}{l}\text { I } \\
\text { II } \\
\text { III } \\
\text { IV } \\
\text { V }\end{array}$ & $\begin{array}{l}65 \\
56 \\
60 \\
60 \\
54\end{array}$ & $\begin{array}{ll}17 \cdot 23 & 1 \cdot 64 \\
17 \cdot 40 & 1.64 \\
17.42 & 1.51 \\
17.07 & 1.53 \\
17.39 & 1.59\end{array}$ & $\begin{array}{l}56 \\
53 \\
66 \\
62 \\
70\end{array}$ & $\begin{array}{ll}16.93 & 1 \cdot 18 \\
16 \cdot 74 & 1 \cdot 14 \\
16 \cdot 75 & 1 \cdot 11 \\
17 \cdot 22 & 1 \cdot 20 \\
17 \cdot 10 & 1 \cdot 10\end{array}$ & \\
\hline Total & 295 & $17 \cdot 30 \quad 1 \cdot 58$ & 307 & 16.951 .15 & \\
\hline
\end{tabular}

Mean Feulgen-DNA absorption values expressed in absorption units $(A U) \pm S . D$.

identical conditions for the comparative numbers were guaranteed. While the absorption measurements of the individual males within all three groups of animals were statistically homogeneous, there were distinct and statistically significant differences $\left(\mathbf{P}_{\mathbf{F}}\right)$ between the variances of the DNA values in most of the $F_{1}$ males in comparison to spermatozoa of NMRI or $M$. poschiavinus measured on the same slide (Table 2). The variances of the Feulgen-DNA values were, however, statistically not significant in the case of the comparative measurements of two slides of Series I (Preparation nos. 1 and $4 ; F_{1}$ against NMRI), even though the standard deviation was greater in the $F_{1}$ than in the NMRI preparations. 


\section{Sperm counts}

The pooled counts of the density of the spermatozoa of nine NMRI and $F_{1}$ hybrid males gave the following mean values:

$$
\begin{aligned}
\text { NMRI } & 757,800 \text { per } \mathrm{mm}^{3} \pm 416,000 \text { S.D. } \\
\mathrm{F}_{1} \text { hybrids } & 523,800 \text { per } \mathrm{mm}^{3} \pm 318,000 \text { S.D. }
\end{aligned}
$$

The difference of 234,000 per $\mathrm{mm}^{3}$ between both mean values is statistically not significant $\left(P_{\mathrm{t}}>0 \cdot 10\right)$.

\section{Viability and morphology of spermatozoa}

The proportion of living spermatozoa (not stained in the eosin-nigrosin test; PI. 2, Fig. 1, but also 4 and 6 ) was $21.4 \%$ in $F_{1}$ males and $19.4 \%$ or $27.2 \%$ in NMRI or $M$. poschiavinus, respectively. The differences are statistically not significant. Similarly, the number of $79.1 \%$ spermatozoa with a normal acrosomal cap (Pl. 2, Fig. 2) in $\mathrm{F}_{1}$ males did not differ significantly from $81.3 \%$ in NMRI and $82.1 \%$ in $M$. poschiavinus.

The mean percentage of abnormal or malformed spermatozoa (Pl. 2, Figs. 5 to 6 ) was $9.6 \%$ in counts from nine $F_{1}$ males. This frequency is significantly higher than the respective comparative value of $2.7 \%$ in nine NMRI or of $1.7 \%$ in seven $M$. poschiavinus males $(P<0.001)$.

The results of the planimetric measurements of the heads of 'normal' and unstained (living) spermatozoa are shown in Text-fig. 3. The peaks of the variation curves of NMRI and $M$. poschiavinus are both distinctly higher than the peak for $F_{1}$ spermatozoa. The distribution is unimodal in the three groups. The mean measurements of $22.74 \mu \mathrm{m}^{2}$ in $\mathrm{F}_{1}$ males is significantly lower $(P<0.01)$ than the mean values of $24 \cdot 18 \mu \mathrm{m}^{2}$ for NMRI and of $23 \cdot 25 \mu \mathrm{m}^{2}$ for $M$.poschiavinus.

\section{Evaluation of the motility of the spermatozoa}

The motility of spermatozoa, of NMRI and $F_{1}$ hybrid males, suspended in glucose solution as well as in Ringer solution was assessed at hourly intervals for $27 \mathrm{hr}$. The curves shown in Text-fig. 4 represent the mean values of nine animals of both groups as expressed in grades of the motility index according to Emmens (1947). There were no significant differences between the spermatozoa of the NMRI and of the $F_{1}$ hybrid males.

\section{DISCUSSION}

The chromosome counts of meiotic metaphase II plates made in the course of this study confirmed similar observations presented in a previous paper (Tettenborn \& Gropp, 1970). The combined results emphasize the prevalence of regular anaphase I disjunction and of euploid M II figures in the parental strains, on one hand, and the importance of structural heterozygosity in the (M. poschiavinus $\times \mathrm{NMRI)} \mathrm{F}_{1}$ males in inducing meiotic non-disjunction on the other hand. In fact, less than $50 \%$ of all $M$ II plates in the $\mathrm{F}_{1}$ animals were euploid while the proportion of euploid M II figures was $95.2 \%$ in NMRI and $93 \cdot 1 \%$ in $M$. poschiavinus.

The cytophotometric assay on Feulgen-stained smears was used for the estimation of DNA because this method gives sufficiently accurate information 


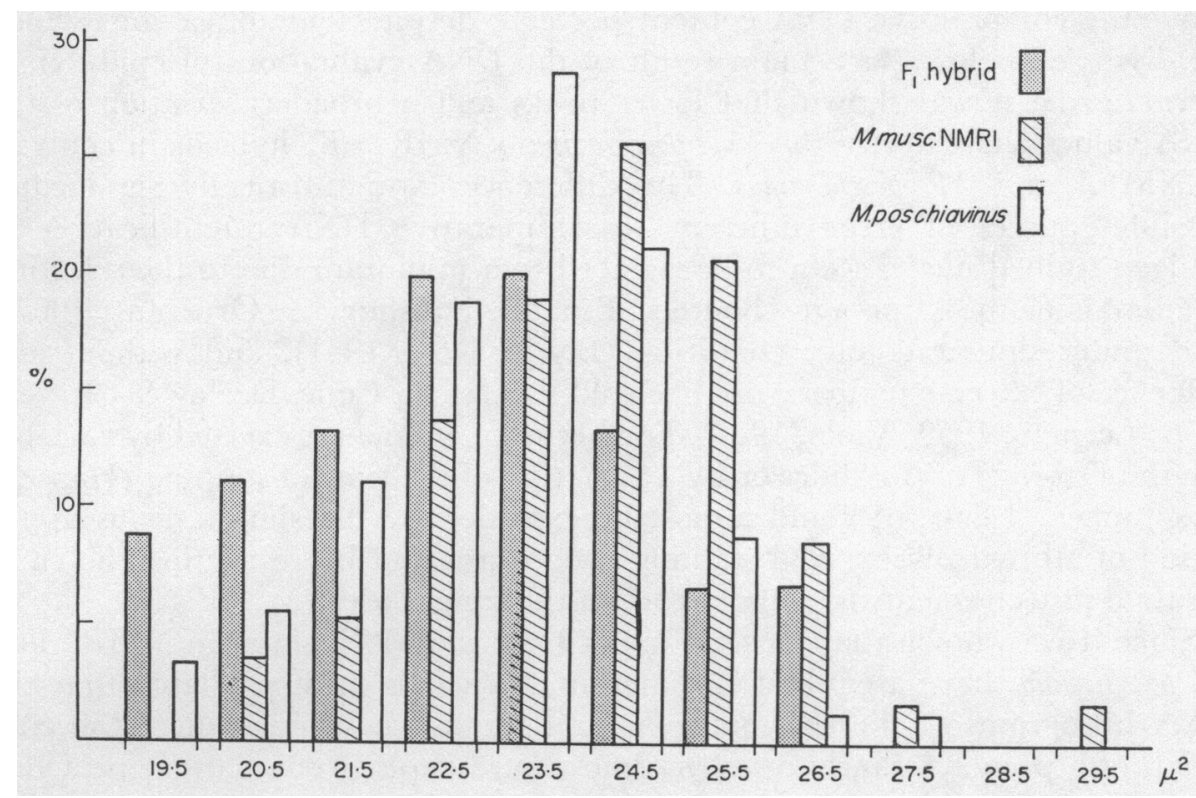

TeXt-FIG. 3. Frequency distribution of planimetric measurements of the heads of spermatozoa of NMRI, $M$. poschiavinus and $\mathrm{F}_{1}$ hybrid males.

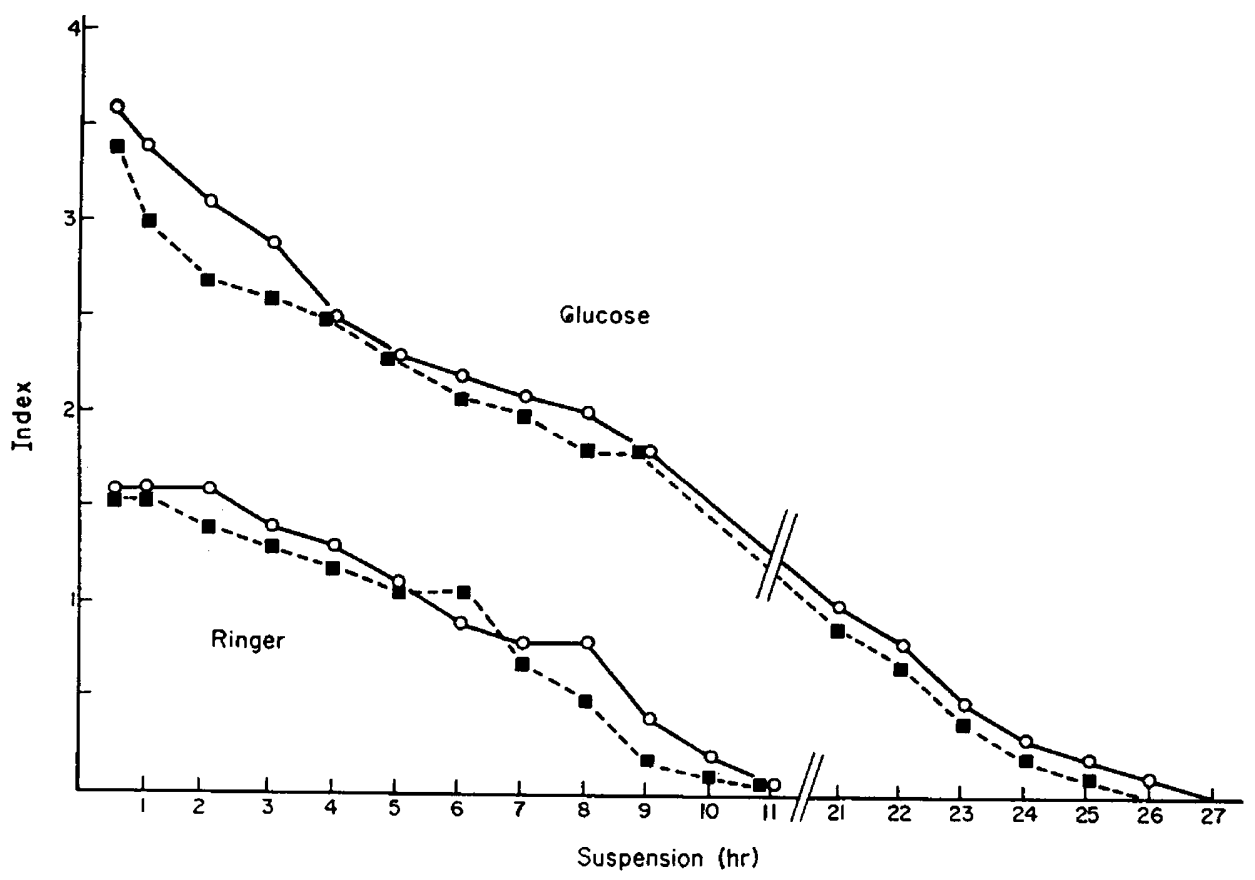

TEXT-FIG. 4. Motility index of NMRI $(0)$ and $F_{1}$ hybrid (e) spermatozoa (mean values from nine males of each group) at different time intervals following suspension in glucose medium or Ringer. 
about the comparative DNA content per cell, despite some objections which are discussed below. As a main result of the DNA evaluations of epididymal spermatozoa, it was shown that lower peaks and a broader variation of the DNA values characterize the $(M$. poschiavinus $\times \mathrm{NMRI}) \mathrm{F}_{1}$ hybrids in contrast to NMRI and $M$. poschiavinus. The differences are statistically significant. Possible sources of error inherent to comparative DNA quantification in Feulgen-stained nuclei seem to be reduced to a minimum due to the selection of animals of the same age (Bouters, Esnault, Salisbury \& Ortavant, 1967), held under similar dietary condition (Ely \& Ross, 1951), and without any influence of extreme temperature like cold shocks (La Cour, Deeley \& Chayen, 1956; Leeman, 1959; Viola, 1964). Furthermore, influences exerted by variable length of storage of the slides or by a variation of the time of staining (Hauschteck-Jungen, 1970a, b) could almost be excluded by the simultaneous application of all hydrolysing and staining procedures and by restricting the comparative measurements to cells spread on the same slide.

Since it was shown that the vast majority of the M II plates in NMRI and $M$. poschiavinus have a euploid chromosomal set, it is most probable that the DNA histograms of the spermatozoa from these two strains reflect the condition of a preponderantly or even almost pure euploid population, provided that euploid secondary spermatocytes do not produce aneuploid spermatozoa at a considerable rate. Though unexplained, slight but significant differences of the absolute DNA content of the spermatozoa of different individuals have been observed in man (Sandritter \& Grosser, 1964), and in boars (Leidl \& Stolla, 1969), the assumption of the constancy of the Feulgen DNA content of spermatozoa of different euploid mouse strains is stressed by the study of Godowicz \& Krzanowska (1966), who determined (also by a chemical method) the absolute DNA content per spermatozoon to be about $4.5 \times 10^{-9} \mathrm{mg}$.

Therefore, the conclusion may be drawn that the greater variation of the DNA content of (NMRI $\times M$. poschiavinus) $\mathbf{F}_{1}$ spermatozoa is due to the marked karyotypical heterogeneity in the presence of an important fraction of aneuploid spermatozoa. This variation seems to parallel the distribution of euploid and aneuploid M II counts in the precursor cells of the mature spermatozoa. It is, therefore, probable that a considerable proportion, if not a majority, of aneuploid (hypomodal as well as hypermodal) secondary spermatocytes develop into cytologically mature spermatozoa of normal shape and appearance, since only such spermatozoa had been selected for the DNA measurements. It is not possible, however, to determine the exact proportion of euploid $(n=20)$ and aneuploid $(\mathrm{n}<$ or $>20)$ spermatozoa of the $\mathrm{F}_{1}$ males by comparing their respective DNA histograms with those of NMRI and $M$. poschiavinus males. A massive loss or degeneration of the aneuploid precursor cells in the course of their maturation in $F_{1}$ males can almost be ruled out by the absence of a statistically significant difference of the sperm counts in NMRI and $F_{1}$ males. In the $F_{1}$ animals, a rise of the frequency of morphologically abnormal spermatozoa $(9.6 \%)$ was observed. However, their number did not seem to be sufficiently great to warrant special DNA measurements of statistical relevance. The assumption may nevertheless be correct that the chromosomal imbalance of aneuploid precursor cells is at least one of the factors responsible for the 
increase of the frequency of malformed spermatozoa. Yet the importance of further peristatic or genetic factors cannot be excluded. Among others, gene imbalance could act also in the chromosomally euploid, but variably recombined, heterozygote genome of the $F_{1}$ spermatozoa. Thus, according to Braden (1959) and Beatty \& Sharma (1960), sperm morphology and the frequency of sperm abnormalities are determined genetically or may be controlled by a factor located on the Y chromosome (Krzanowska, 1966, 1969). In both parental strains (NMRI and $M$. poschiavinus), the percentage of sperm abnormalities was very small and was least in $M$. poschiavinus $(1.7 \%)$ which contributed the $\mathrm{Y}$ chromosome to the $\mathrm{F}_{1}$ males. This observation is in contrast to the conclusions drawn by Krzanowska (1969) from her findings in crosses of the $\mathrm{KE}$ and CBA strains.

Without doubt, a genetic factor inherent to the recombined heterozygote haploid genome of the (NMRI $\times M$. poschiavinus) $F_{1}$ spermatozoa is responsible for the variation of the head area of the $F_{1}$ spermatozoa in comparison to both NMRI and $M$. poschiavinus. Yet, the fact that the mean area occupied by the head of $F_{1}$ spermatozoa is lower than in the parental strains is noteworthy compared to observations of heterosis in sperm heads in outbred strains or in crossings between inbred strains of mice reported by Beatty \& Sharma (1960), Sharma (1960) or Godowicz \& Krzanowska (1966).

The variation in the DNA content, the frequency of malformations, and the area of the head are the only morphological or functional criteria of the spermatozoa which differ in the $F_{1}$ animals and the parental strains. No significant variation exists for the respective proportions of living spermatozoa in the eosin-nigrosin test or for spermatozoa with a normal acrosomal cap as well as for the motility of the spermatozoa. It can therefore be assumed that the presence of a fraction of aneuploid spermatozoa in $F_{1}$ animals does not affect the statistical variation of the latter properties in the different groups of animals investigated.

Our results show that aneuploid precursor cells in spermatogenesis may develop at a considerable rate to cytologically mature aneuploid spermatozoa. They eventually constitute a fraction of the total number of morphologically and functionally 'normal' spermatozoa, even though some aneuploid precursor cells may degenerate or produce malformed spermatozoa. These observations may provide better means for a comprehensive analysis of gametogenesis as a link in the sequential relationship of abnormal meiotic segregation, zygotic aneuploidy and reproductive failure.

\section{AGKNOWLEDGMENTS}

This study was supported by a grant (No. Gr 71/28) of the Deutsche Forschungsgemeinschaft, Bad Godesberg. For their introduction in the use of the Barr \& Stroud integrating microdensitometer and for advice, the authors are indebted to Dr H. G. Schwarzacher and Dr F. Pera, Anatomisches Institut der Universität, Bonn. 


\section{REEERENCES}

Beatty, R. A. \& Sharma, K. N. (1960) Genetics of gametes. III. Strain differences in spermatozoa from eight inbred strains of mice. Proc. R. Soc. Edinb. B, 68, 25.

Bouters, R., Esnault, G., Salisbury, G. W. \& Ortavant, R. (1967) Discrepancies in analyses of deoxyribonucleic acid in rabbit spermatozoa, involving Feulgen staining (Feulgen-DNA) and ultraviolet light absorption (UV-DNA) measurements. F. Reprod. Fert. 14, 355.

Braden, A. W. H. (1959) Strain differences in the morphology of the gametes of the mouse. Aust. $\mathcal{F}$. biol. Sci. 12, 65 .

GARR, D. H. (1970) Chromosome abnormalities and spontaneous abortions. In: Human Population Cytogenetics, Pfizer Medical Monographs No. 5, pp. 103-118. Edinburgh University Press.

ELy, J. O. \& Ross, M. H. (1951) Deoxyribonucleic acid content of rat liver nuclei influenced by diet. Science, N.Y. 114, 70.

Eмmens, C. W. (1947) The motility and viability of rabbit spermatozoa at different hydrogen-ion concentrations. F. Physiol., Lond. 106, 471.

Evans, E. P., Breckon, G. \& Ford, C. E. (1964) An air-drying method for meiotic preparations from mammalian testes. Cytogenetics, 3, 289.

Ford, G. E. (1970) The population cytogenetics of other mammalian species. In: Human Population Cytogenetics, Pfizer Medical Monographs, No. 5, Edinburgh University Press.

Godowicz, B. \& KRZANowskA, H. (1966) DNA content of mouse spermatozoa from inbred strain KE of low male fertility. Folia biol., Krakow, 14, 235.

Gropp, A., Tettenborn, U. \& von Lehmann, E. (1970) Chromosomenvariation vom Robertson'schen Typus bei der Tabakmaus, $M$. poschiavinus, und ihren Hybriden mit der Laboratoriumsmaus. Cytogenetics, $9,9$.

Gropp, A., TetTEnBorn, U. \& LEONARD, A. (1970) Identification of acrocentric chromosomes involved in the formation of "Fusion"-Metacentrics in mice. Experientia, 26, 1018.

HaNcock, J. L. (1951) A staining technique for the study of temperature-shock in semen. Nature, Lond. 167, 323.

Hauschteck-Jungen, E. (1970a) Quantitative DNA-Bestimmungen von Ameisenhirnzellen. I. Abhängigkeit der DNS-Werte von der Dauer der Feulgenfärbung. Histochemie, 21, 141.

HaUsGhtEck-JUngen, E. (1970b) Quantitative DNS-Bestimmungen von Ameisenhirnzellen. II. Einfluss der Umwelt auf die Feulgen-Extinktionswerte. Chromosoma, 32, 79.

KRzANowsKa, H. (1966) Inheritance of reduced male fertility, connected with abnormal spermatozoa, in mice. Acta biol. cracov, (Zool.), 9,61.

KRZANOWSKa, H. (1969) Factor responsible for spermatozoan abnormality located on the Y chromosome in mice. Genet. Res. 13, 17.

La Cour, L. F., Deeley, E. M. \& Chayen, J. (1956) Variations in the amount of Feulgen stain in nuclei of plants grown at different temperatures. Nature, Lond. 177, 272.

LEEMAN, L. (1959) Deoxyribonucleic acid content of the cell nuclei in the adrenal medulla after exposure to low temperatures. Nature, Lond. 183, 1188.

LeIdL, W. \& STOLLA, R. (1969) Individual difference of UV-DNA in spermatozoa of boars. F. Reprod. Fert. 18, 173.

SANDRITTER, W. \& Grosser, K. D. (1964) Quantitative histochemische Untersuchungen an Spermien. Symp. Biol. Hung. 4, 63.

Sharma, K. N. (1960) Genetics of gametes. IV. The phenotype of mouse spermatozoa in four inbred strains and their $\mathrm{F}_{1}$ crosses. Proc. R. Soc. Edinb. B, 68, 54.

TetTEnborn, U. \& Gropp, A. (1970) Meiotic nondisjunction in mice and mouse hybrids. Cytogenetics, 9, 272.

Viola, M. (1964) Marked decrease of DNA in the nuclei of the adrenal medulla of rats exposed to cold. Nature, Lond. 204, 1094. 